\title{
Buyer (dis)satisfaction and process innovation: the case of information technology services provision
}

Article

Accepted Version

Creative Commons: Attribution-Noncommercial-No Derivative Works 4.0

Ashok, M., Day, M. and Narula, R. (2018) Buyer (dis)satisfaction and process innovation: the case of information technology services provision. Industrial Marketing Management, 68. pp. 132-144. ISSN 0019-8501 doi: https://doi.org/10.1016/j.indmarman.2017.10.004 Available at https://centaur.reading.ac.uk/73127/

It is advisable to refer to the publisher's version if you intend to cite from the work. See Guidance on citing.

To link to this article DOI: http://dx.doi.org/10.1016/j.indmarman.2017.10.004

Publisher: Elsevier

All outputs in CentAUR are protected by Intellectual Property Rights law, including copyright law. Copyright and IPR is retained by the creators or other copyright holders. Terms and conditions for use of this material are defined in the End User Agreement.

www.reading.ac.uk/centaur 
Central Archive at the University of Reading

Reading's research outputs online 


\title{
BUYER (DIS)SATISFACTION AND PROCESS INNOVATION: THE CASE OF INFORMATION TECHNOLOGY SERVICES PROVISION
}

\begin{abstract}
Studying buyer satisfaction within business services is important because if buyer expectations are not addressed, it can endanger the relationship. Dissatisfied buyers can remain silent or switch supplier without notice, damaging the supplier-buyer relationship. Therefore, suppliers often invest substantial effort in collecting feedback with an expectation that it will foster improvements and innovation in processes. However, using a mixed method sequential research design, we find that there is no direct association between the level of dissatisfaction and process innovation: this poses questions about redundancy of feedback collection. We find that there is a time lag between dissatisfaction identification and problem resolution. We also find that there is a cognitive gap between a supplier's interpretation of the buyer's expectations and the buyer's actual expectations. Further, existing processes that are improved repetitively using discontent feedback suffer from diminishing returns. Suppliers need to proactively seek solutions rather than reactively dealing with buyer problems.
\end{abstract}

Keywords: buyer collaboration, buyer (dis)satisfaction, internal resource commitment, information technology services, mixed method, process innovation. 


\section{INTRODUCTION}

The impact of buyer satisfaction for a supplier has significant implications because losses from dissatisfied customers are potentially greater than the gains from those who are satisfied (Anderson and Sullivan, 1993). It costs more to replace than retain a customer (Lapré, 2011). Dissatisfied buyers can have damaging effects on multiple fronts (Yi, 1990; Ferguson and Johnston, 2011; Cho and Song, 2012). Thus, buyer satisfaction is academically and managerially relevant, and assessing satisfaction in a services context is therefore a twofold challenge. First, services are defined by their simultaneity of production and consumption, which involves continuous interaction between buyer and seller who communicate, coordinate and adapt activities. The depth of this interaction (positive and negative) shapes the service exchange; hence 'servicing' a buyer's needs gives a partial explanation of knowledge intensive bonds. Second, the complexities arising from service consumption/production simultaneity elevates the importance of managing service interactions, especially where processes involving the end consumer are impacted. Relational complexity in business services is well suited to theorizing with an interaction approach because it allows the assessment of the detailed exchange processes involving buyer satisfaction (Hakansson, 1982). According to Wynstra et al. (2006) interaction encompasses the communication, co-ordination, and the adaptation of activities and resources that buyers and suppliers are using or providing in the relationship. Relational governance mechanisms are therefore communication patterns, administrative routines and systems understood as features of co-ordination behaviours among different parties (Hakansson and Snehota, 1995).

Where differences exist in perceptions, frictions in relational exchange are created and will be articulated as dissatisfaction. In this context, value is not just the provision of service at the request of a buyer but also a problem-coping process. This accounts for an "actor's 
interpretation of the worth of the service's contribution towards coping with one or more specific problems of the actor, identified by that actor" (Ford and Mouzas 2013, p. 12).

Suppliers failing to satisfy buyer expectations can use feedback as an enabler of process innovation to address the shortcomings, which can lead to innovations (Dong et al., 2008; Lapré, 2011). Such innovations can lead to a supplier's offerings becoming more attractive by improving process efficiency, thereby creating positive goodwill between the parties (Kumar et al., 2010). However, it is unclear if positive supplier outcomes always arise after the buyer signals lower satisfaction (Szymanski and Henard, 2001). Where, although ongoing buyer-supplier interaction is costly, the opportunity to reduce friction in interaction might not be automatically taken up by suppliers. Suppliers seem challenged on many fronts when capitalising on feedback for informing their innovation priorities (Fundin and Elg, 2010). Innovation is not a straightforward linear learning process (Freeman, 1990), with process innovation in particular requiring complex interaction between buyers and suppliers (Santos and Spring, 2015). When dissatisfied, buyers can remain silent, or even switch suppliers, incurring the cost of building a new relationship with another supplier, as well as the costs of abandoning an existing relationship.

Declining levels of buyer satisfaction may encourage greater collaboration to address particular relational frictions. Responding to negative feedback may act as a bond, further 'locking in' the buyer-supplier collaborations (Hakansson and Waluszewski, 2002). However, the benefits derived from dissatisfaction information are unlikely to be automatic. This is because the ability to act on discontent feedback requires commitment of internal resources to develop absorptive capacity (Cohen and Levinthal, 1990). Thus, our research question is: How is buyer feedback used for process innovation within a relational context?

Information Technology Services (ITS) is an ideal empirical context as there is a high degree of human interaction, which is especially prone to failure (Li-hua, 2012). ITS 
provision brings together the supplier's human capital, and the needs and experiences of the buyer. Thus, ITS is a type of 'instrumental service' where buyer-seller dialogue is critical in infoming both parties about the extent to which the service impacts the buyer's primary processes (Van der Valk et al., 2008). ITS delivery involves adapting already customised solutions in response to the often-unique requirements of buyers through exchange. Suppliers of such embedded services depend on multiple points of contact to evolve process innovations, which translate information gained from ad-hoc buyer developments into codified knowledge. This aids the supplier's ability to enhance their organisational routines for projects outside the existing relationship (Miles, 2006; Salter and Tether, 2014). Process development is intrinsic to this type of supplier-buyer relationship, so it becomes hard-toimitate. Responses to different levels of buyer satisfaction could therefore result in noticeable differences in a supplier's strategic resource commitment and interaction. Taking this argument further requires exploring how suppliers respond to different levels of buyer satisfaction, and scholarly research in this area is limited (Van der Valk and Wynstra, 2014).

The paper is structured as follows: the theoretical thrust of the research is explained and hypotheses are drawn together within the context of an interaction approach. Next, the theoretical and methodological rationale for using a novel research design is explained: a sequential quantitative (core) and qualitative (supplemental) mixed method. The point of interface for the results is the discussion where our contribution to theory and practice will tease out the relationships between different levels of buyer satisfaction and ITS firms' process innovation activity.

\section{THEORETICAL BACKGROUND AND HYPOTHESES}

In the context of instrumental services, buyers are also users. They consume and coproduce value with suppliers and expect to benefit from use of a service, within the context of 
on-going interaction. Services are shaped when produced and consumed, causing actors to communicate, co-ordinate and adapt activities and resources according to specific norms accumulated within the interactive atmosphere. Relationships in this context comprise mutually-oriented interactions between two reciprocally committed parties, where over time interdependence is created with both positive and negative features for both parties (Hakansson and Snehota, 1995, p. 25). Buyer satisfaction is defined as temporally specific crystallisation of a buyer's perception of the service (or product or process) versus the buyer's value judgment (needs, wants, or desires); disconfirmation is the gap between the buyer's perception of performance and baseline expectations; where disconfirmation leads to dissatisfaction (Yi, 1990). Although innovation may be a supplier-led activity that does not necessarily rely on buyer collaboration, the on-going buyer-supplier interaction may change the buyer's perception of improved or new methods of service delivery (Johnson and Medcof, 2007). This is particularly important in relation to process innovations, defined as changes to organisational methods leading to outcomes such as higher quality or faster service delivery for one or both parties (Sumo et al., 2016). D'Antone and Santos (2016, p. 183) highlight that interactive relationship for knowledge-intensive business services involve process innovations where "suppliers help their customers improve their work environment and develop capabilities to allocate human resources and money efficiently to innovation activities. As such, [post-purchase interactions] can lead to process innovation within buying organizations".

Schuhmacher and Kuester (2012) suggest buyers dissatisfied with existing services are more likely to be motivated to jointly innovate with the supplier. Buyers are known to enhance products, processes or services for self-use and are often more effective at developing innovations as compared to suppliers (Hienerth et al., 2014). The supplier's strategy towards buyer engagement is also fundamental in services provision, and especially 
so for instrumental services where there is a high degree of interactivity (Van der Valk et al., 2008). Suppliers showing willingness to collaborate with buyers enable access to buyers' need and context of use information, which is not only expensive but also hard to transfer thus cultivating inimitable buyer-supplier bonds (von Hippel, 2005). Buyers also contribute to this sort of problem-solving innovation: they validate latent needs, provide insights into their experience, and share their perspective of the value-in-use of any process innovation (Salter and Tether, 2014). Finally, buyer knowledge has significant relevance for co-created products and services because the consumer and the supplier collaborate jointly to innovate a solution for specific problems (Doroshenko et al., 2013).

Buyer collaboration has two dimensions: the buyer's integration in the process development journey and a buyer's influence in the adoption and diffusion of the process innovation in response to buyer dissatisfaction (see Figure 1).

----Figure 1 about here----

\subsection{Buyer collaboration}

Although not explored in depth by scholars, it is evident that extensive interaction can occur because of low buyer satisfaction that is focused on dealing with specific frictional points in a relationship (Dong et al., 2008). Drawing from studies of new services development it seems to be the case that emergent solutions are the result of joint action (Hakansson et al., 2009; Wiessmeier et al., 2012). In these circumstances buyer involvement stretches beyond knowledge sharing and involves direct engagement in various activities related to problem solving. Lüthje and Herstatt (2004) also suggest this type of interactive collaboration moderates the risk of failure of innovation projects. Furthermore, La Rocca et al. (2016) propose that such involvement entails open-ended mutual commitments between

the interacting actors. Where neither actor can anticipate the features of an emergent solution 
then open-ended mutual commitment is crucial. In this case buyers are better at describing their needs and at visualising the value-in-use of the solution, while suppliers should have a better ability to develop the solution (von Hippel, 2005). Joint working will also open up access to the buyers' knowledge; and this enhances the translation of needs into successful process, product or service innovation (Lüthje and Herstatt, 2004). The engagement of buyers with the potential to influence the success of new processes improves the market acceptability of this innovation (Bilgram et al., 2008). Hence;

Hypothesis 1 (H1). Buyer collaboration is a second-order latent construct whose subdimensions are buyer integration (H1a), and buyer influence (H1b).

\subsection{Internal resource commitment}

A key reason for collecting satisfaction information from buyers is to focus on process innovation activity. But, such feedback can be the cause of friction between old and new knowledge in the relationship, and be reflected into the supplier's operations. Hakansson and Waluszewski (2002) term this the 'heaviness' of relationships, and elements of the resource mix available to suppliers will require recombination. Suppliers will therefore need to dedicate social, economic and political resources and create management practices to enable an absorptive capacity for process innovation. Supplier adaptation can have a positive side effect, signalling commitment from the buyer's perspective that can be perceived as a strengthening of their supply base (Walter and Ritter, 2003). Foss et al. (2011) find a mixture of outward and inward-looking management practices to be the most effective resource mix. Internal resource commitment in the form of inward-looking supplier management practices of executive management engagement and continuous investment, and the outward-looking management practice of process benchmarking with peers are investigated in this paper. 
It is clear that executive management play a key role in defining the interactive strategy to address dissatisfaction. Karatepe (2006) concludes that executive support for training, change enablement and rewarding is critical in creating an appropriate atmosphere for complaint response. Executive management thus enable joint working by creating an atmosphere of open dialogue, and transparency. Similarly, executives guide organisational behaviour in response to discontent in order to avoid negative buyer experience (Ferguson and Johnston, 2011).

Continuous investment is an important dimension of resource commitment, because it enables firms to develop absorptive capacity that facilitates the translation of knowledge into firm-specific learning and capabilities (Nicolajsen and Scupola, 2011). Continuous investment is essential for firms to integrate new information with existing knowledge.

As part of resource commitment, benchmarking is an organisational improvement strategy to assess a firm's process performance as against that of their competitors and industry trends (Camp, 1989; Dattakumar and Jagadeesh, 2003; Anderson and McAdam, 2004). Continuous benchmarking can signal, in the event of high levels of dissatisfaction, that a firm will be dependent on buyers rather than external best practices to understand the failure points causing the discontent. Hence,

Hypothesis 2 (H2). Internal resource commitment is a second-order latent construct whose sub-dimensions are executive management engagement (H2a), continuous investment (H2b) and process benchmarking (H2c).

\subsection{Buyer collaboration, internal resources and process innovation}

Engaging in process innovation in response to buyer dissatisfaction should provide several benefits to the supplier. It generates efficiency gains through cost controls and improved capabilities, and delivers added value to the buyer through productivity gains and 
enhanced quality (Davenport, 1993). However, it is unclear how process innovation at the firm-level (Keupp et al., 2012) is influenced by buyer collaboration and internal resource commitment on process innovation if buyer dissatisfaction is the trigger.

\subsubsection{Buyer interaction and process innovation}

Continual patterns of mutually beneficial interaction provide access to capabilities and knowledge residing within a firm's network and partners; and the importance of learning from external knowledge is well documented for service suppliers (Frow et al., 2016). In the context of ITS, suppliers tend to be more dependent on external knowledge as compared to manufacturing businesses, and they benefit substantially from end-buyer collaboration (Salter and Tether, 2014). Service suppliers therefore have greater dependence on buyer knowledge for innovation (Doroshenko et al., 2013). As a result,

Hypothesis 3 (H3). Buyer collaboration has a positive direct impact on joint process innovation.

\subsubsection{Internal resource commitment and process innovation}

Access to external knowledge (resources or capabilities) does not generate financial gains automatically (Frow et al., 2016). Firms need to commit resources so capacity can be developed to translate new information into firm-specific learning, and thereby diffuse knowledge for commercial gains (Cohen and Levinthal, 1990). The commitment of internal resources is essential to develop absorptive capacity so firms can maximise the value extracted from internal and external knowledge sources for innovation (Ashok et al., 2016), hence:

Hypothesis 4 (H4). Internal resource commitment has a positive direct impact on joint process innovation. 


\subsubsection{Buyer collaboration, process innovation and internal resource commitment}

Frow et al. (2016) emphasise the need to study co-creation of value practices in professional services, as the gains from end-buyer collaboration are contingent on the translation of knowledge into organisational learning (Nicolajsen and Scupola, 2011). Foss et al. (2011) and Ashok et al., (2016) report an indirect effect of customer collaboration on innovation performance, mediated by organisational practices. For knowledge intensive firms, the investment of resources in developing the internal capability to learn from diverse sources is especially important (Salter and Tether, 2014). As a consequence, we study the interplay of internal resource commitment with buyer collaboration in enhancing joint process innovation and hypothesise,

Hypothesis 5 (H5). Buyer collaboration has an indirect impact on joint process innovation and is mediated by internal resource commitment.

\subsection{The moderating role of buyer dissatisfaction}

According to Keupp and Gassmann, (2013) and Kim et al., (2014) suppliers facing high buyer discontent begin by quickly addressing tactical improvement targets, achieved by exploiting knowledge similar to the existing knowledge-base. Therefore, we expect suppliers experiencing high-levels of dissatisfaction to interact more intensively with a buyer to identify solutions for service and process failures. Similarly, the time immediately following the process failure is critical because this is when it is the most difficult to stimulate collaboration. Thus, we expect suppliers experiencing high discontent to show a greater interest in improving the adoption and diffusion of process change that is initiated to address dissatisfaction. We therefore hypothesise:

Hypothesis 6 (H6). The level of buyer dissatisfaction moderates the direct relationship between buyer collaboration and joint process innovation. 
Similarly, suppliers experiencing high discontent will be anxious to find a mechanism to reduce or eliminate the cause of buyer dissatisfaction, and to learn from the buyer feedback in order to improve their current capabilities. However, Kogut and Zander (1992) shows that the efficient translation of external knowledge into the organisational context requires investment of internal resources. Thus, we propose that:

Hypothesis 7 (H7). The indirect relationship between buyer collaboration and joint process innovation (through internal resource commitment) is also moderated by the level of buyer dissatisfaction.

In an interactive context, suppliers learn with buyers and can jointly devise a strategy to increase the buyers' satisfaction (Ferguson and Johnston, 2011). In addressing different levels of dissatisfaction, suppliers face stark choices about directing internal resources. This is because a buyer's role in formulating a response to dissatisfaction evolves. It is expected that the level of investment will mirror the level of (dis)satisfaction. This is because suppliers will invest in new process thinking to break away from the old ways of working. However, the supplier's ability to benefit from collaboration is path-dependent, and reliant on on-going investment of resources (Kang and Kang, 2014). We therefore posit that internal resource commitment will be more evident for suppliers responding to higher (versus lower) dissatisfaction. Hence;

Hypothesis 8 (H8). The relationship between internal resource commitment and joint process innovation will be moderated by the level of buyer dissatisfaction.

\section{MIXED METHOD APPROACH}

We use a sequential mixed method (quantitative, then qualitative) to assess the model in Figure 1 as there are two key stages required to identify whether buyer dissatisfaction is at 
play as a moderator when the capabilities of buyer collaboration and internal resources are assessed as determinants of process innovation. Following the logic outlined by Tikkanen et al. (2000) we expected the quantitative element to be limited in its ability to give depth of insight if other relational factors were at play when buyer dissatisfaction was present. A cross-sectional quantitative assessment of model fit does not explain what may be specific contextual factors pertaining specifically to internal resource commitment, nor would it be possible to account for any temporality of exchange (lag effect) of dissatisfaction data as an impetus for process innovation. Then, the qualitative element is particularly important as we wish to establish if internal resource commitment and buyer collaboration are important for buyer satisfaction. Given these complexities Morse and Niehaus (2009) advocate a "QUAN>qual" design: a dominant quantitative stage for initial model testing with a subservient (focused) qualitative element to shed light on potentially confounding results.

Mixed methods give greater, focused power to data interpretation and can be a superior for highlighting convergence, inconsistency, and contradiction across the data sources (Johnson et al., 2007). Creswell (2013) define the QUAN>qual as an explanatory sequential mixed method - phased one (quantitative) must inform the design of a focused phase two (in-depth qualitative interviews). Survey research was first undertaken to study if ITS suppliers distinguish their organisational strategy in response to different levels of buyer dissatisfaction. The qualitative element enriches insight into the issues impacting process innovation by deepening the explanation of the contextual factors pertaining to the interactive atmosphere surrounding buyer collaboration and internal resource commitment.

When writing up the results of a mixed method study Morse and Niehaus (2009) advocate the point of interface between the two methods is the results narrative. Developing the connection between the methods requires different data sources and literature to be interplayed back and forth (Dubois and Gadde, 2002). The results of the qualitative 
(supplementary) element are therefore integrated with those of the quantitative (core) component, adding literature to a discussion section so that the qualitative results deepen the quantitative component. It permits a statistical test of the overall relationship between process innovation and its factors: buyer collaboration and internal resource commitment, and the qualitative component deepens insight into the interactive frictions from buyer dissatisfaction.

\subsection{Sampling strategy}

ITS professionals were targeted who have day-to-day experience of co-creating IT services as suppliers. Social networks are fundamental mechanisms of connection in the ITS industry to communicate with its online-active buyers, and to exploit the valuable knowledge exchanged on such networks (Ridder, 2013). We used two novel sources, experienced network members of Henley Business School (University of Reading, UK) postgraduate programmes for experienced professionals, and a professional networking site (LinkedIn), to elicit engagement. Purposive sampling of this nature and respondent engagement processes took much longer compared with a stratified random sample and mail survey, but it secured responses from experienced professionals to enhance reliability. A sample of 615 respondents of ITS suppliers yielded 166 usable surveys - a 27 percent response rate and comparable with previous studies (Baruch and Holtom, 2008; Foss et al., 2011; Sauermann and Roach, 2013). Steps were taken to improve the response-rate and their accuracy, including: upfront personalised email contact with respondents (Cook et al., 2000) to explain the context and potential business implications of the survey, asking them how much they knew about their firm's perspective concerning the research topic, assuring confidentiality, and offering a copy of the summary results. Two reminders were sent with links to the online survey at two-week intervals. Bartlett et al. (2001) and Hair et al.'s (2013) guidelines were followed to ensure the 
sample size was adequate to conduct the analysis. Appendix 1 shows the constructs and the measurement scale.

For the supporting qualitative element, 13 executives participated in in-depth semi structured interviews and did not participate in the quantitative survey. They were selected because of their extensive knowledge of the research topic, with Table 1 capturing the titles and professional experience of the interviewees.

----- Table 1 about here-----

\subsection{Quantitative Study}

Joint process innovation and buyer dissatisfaction are first-order constructs. We use multi-item scales to measure these constructs, and as there is no extant scale for each routine bundle we follow a rigorous item purification process guided by Churchill (1979). We further improved the content validity of the items through interviews with twenty-eight ITS executives who assessed the scales. We also pilot tested the instrument by asking 41 ITS executives of a target group closely matching but different from the main study participants to complete the survey following the same instrument distribution method as the final survey. The research model is reflective, where the indicators are created to reflect the underlying construct (Chin, 1998a). Reflective indicators are defined on a one-to-seven scale (strongly agree to strongly disagree) because it allows the capturing of a greater variation than a fivepoint scale (Lietz, 2010).

Since one respondent at each supplier provided the data for our study, we tested for the effects of common method variance by conducting Harman's single-factor test (Podsakoff and Organ, 1986). We did not find any general factor that accounted for most of the variance in these variables; hence common method variance is not a problem in our study.

\subsection{Method of analysis}




\subsubsection{Survey data analysis}

Exploratory factor analysis identifies the underlying structure of the indicators in the study (Hair et al., 2010). Principal components analysis (PCA) using varimax rotation extracts latent variables to support the objective of finding a parsimonious solution with reduced data (Hair et al., 2010).

We analysed the data in SmartPLS (Ringle et al., 2005). PLS-SEM (partial least squares - structural equation modelling) is suitable for this study based on guidance from Henseler et al., (2009) and Hair et al. (2013). We seek to maximise the prediction of the endogenous factor and at analysing theory in its early stage of development. Further, PLSSEM is distribution-free and achieves a higher statistical power with smaller samples. Finally, PLS estimates remain consistent for large number of indicators per latent variable, and it supports a complex model design.

Redundancy among the indicators was also addressed (Cronbach, 1951). Two groups (representing high- and low-levels of buyer dissatisfaction) were defined by splitting the buyer dissatisfaction latent variable across the median (per guidelines from Sosik et al., 2009). This gave 68 sample cases for the high-level of buyer dissatisfaction sub-group and 69 cases for the low-level of buyer dissatisfaction sub-group.

\subsection{Quantitative Data Results}

We adopt the guidelines set out in the literature to test a reflective outer and inner model using PLS-SEM. The outer (measurement) model is assessed for reliability and validity of the constructs (results in Table 3), using guidelines set out in Henseler et al., (2009) and Hair et al. (2013). Firstly, the composite reliability measure for all constructs across the sub-groups reported greater than 0.89 composite reliability values, thus exceeding the 0.7 criterion. The construct's convergent validity is confirmed by average variance 
extracted (AVE) scores greater than 0.5 for all the constructs across the sub-groups. Finally, discriminant validity is confirmed by the qualitative assessment of face validity, by checking indicator construct cross-loadings, and by examining that the square root of the construct's AVE was greater than the correlation with the other constructs (Table 4). Bootstrapping analysis is undertaken to ascertain cross-loadings, using 5000 sub-samples and the number of cases for each sub-group.

----- Tables 3 and 4 about here-----

PLS-SEM does not have a global goodness-of-fit index hence various tests of the inner model are reported (Table 5). Concerning the multi-collinearity of the predictor constructs; all VIF values are less than five, and so is not a concern (Hair et al., 2013). We undertook blindfolding to ascertain the model has predictive relevance, since $\mathrm{Q}^{2}$ values are greater than zero for both the endogenous variables across the sub-groups (Hair et al., 2013). The explanatory power or $\mathrm{R}^{2}$ of the dependent variable process innovation is 0.45 and 0.62 across the high and low buyer dissatisfaction sub-groups; hence meeting the criterion that the $\mathrm{R}^{2}$ value should be around 0.30 to be considered satisfactory (Chin, 1998b).

The standardised path coefficients (and their t-values) obtained through bootstrapping are used to test the hypotheses (Figure 2). Effect sizes are compared (using Cohen's (1992) guidelines) of the predictor constructs on the endogenous constructs (Table 5). Construct mean values are compared across the sub-groups (Table 6). Finally, the significance of the path coefficient differences is assessed (Table 7). Special attention is paid to check that the standardised path coefficients are at least 0.20 so as to be considered meaningful (Chin, 1998a). Summarised results appear in Table 8.

----- Figure 2 about here-----

----- Tables 5, 6, 7 and 8 about here----- 
The results suggest that ITS suppliers are only likely to distinguish their approach towards the factor buyer influence (on the adoption and diffusion of the innovated process). Suppliers facing high-levels of dissatisfaction are likely to show greater evidence of such collaboration. Further, the investigation of the path coefficients (captured in Table 7) shows that there is no difference across the sub-groups. Therefore, ITS suppliers in our sample show no difference in the impact of buyer collaboration (directly or indirectly) or of internal resource commitment on process innovation based on high- versus low-level of buyer dissatisfaction.

The survey results are perplexing, so deeper exploration through interviews is justified to explain why there appears to be no impetus for suppliers to improve even when buyers are dissatisfied (see Table 8). Thus, we explore how ITS suppliers use the insights offered by the dissatisfaction feedback to explore facets of 'heaviness' (potential factors related to technical development) that do not result in process innovation (Hakansson and Waluszewski, 2002). A more complex relationship between dissatisfaction and process innovation therefore exists and needs elaborating to understand the results of $\mathrm{H} 6-\mathrm{H} 8$.

\subsection{Qualitative Study}

A thematic analysis technique - template analysis built on the outcomes of literature and the survey analysis - was used to identify, analyse, interpret and report the themes emerging from a focused section of the model (Braun et al., 2015). Compared with a grounded approach it permits the researcher to take theoretical propositions into the analysis (Braun and Clarke, 2006; King, 2012). A six-step process was followed for the analysis (King, 2012). First, a-priori themes were developed using the literature review and compared with the outcomes of the quantitative study. Second, the interviews were transcribed and familiarised with. Third, commonly occurring themes (or patterns) in the data were identified 
and codes (or labels) were attached to the text. Fourth, an initial hierarchical coding template was created after reading the first transcript. Fifth, the codes and themes were revised after reading all the transcripts and the template was further modified and tested (Table 2 captures the final coding template). Finally, a thematic presentation of the findings was undertaken which led to the integration of findings (see Figure 3).

----- Table 2 about here-----

------Figure 3 about here ------

\subsubsection{Triggers and timing: temporality in process innovations}

Interestingly, nine of the thirteen executives interviewed were not surprised to see the lack of association of buyer dissatisfaction with process innovation. An inability by suppliers to translate buyer discontent feedback into process change outcomes seems to be a consequence of repeated improvement activities - based on failed processes - reaching a benefit plateau. By contrast, the experiences of the remaining respondents (four executives) were that dissatisfaction had almost always been one motivator, but not necessarily the cause of process innovation.

Firstly, we report the experiences of the four executives expecting a relationship between dissatisfaction and process innovation outcomes (theme 1, Table 2); the theme uniting them is that dissatisfaction is a stimulus for process change occurring later (a temporal issue) in their organisational context. Two sub-themes (themes 1.a and 1.b, Table 2) emerge from these discussions highlighting the experiences (or expectations) that ITS suppliers are wholly reactive, and undertake process innovation as a result of buyer dissatisfaction, namely:

"Usually IT Service firms collect customer (dis)satisfaction first then decide to change the processes. IT Service firms are usually reactive; they initiate process 
change in response to customer dissatisfaction. However, there is a time lag between the expression of dissatisfaction and the implementation of process innovation."

Theme 1.b summarises the executives' reflections that unmet buyer needs (and dissatisfied buyers) motivate relationship-specific process change, for example:

"Any process innovation at its root will always have a problem statement to solve.

The problem statement will come from a problem faced by an existing customer or an existing process, primarily. In my experience a significant percent of process innovation we see definitely hit an existing problem and a small percent hit a generic opportunity in the market. [...] If I have a problem I want to solve it."

Detailed deliberations of the remaining nine executives provided a contrasting perspective in relation to ITS suppliers' dependence on process failure and the role of buyer dissatisfaction as a trigger for process change (theme 2, Table 2). In their experiences, the reluctance or inability of dissatisfied buyers to leave a supplier - for a variety of reasons was often construed as a supplier's success in retaining unhappy buyers. However, dissatisfied buyers who do not switch providers can spread negative comments about their experiences and damage a firm's image (Yi, 1990; Ferguson and Johnston, 2011). Five subthemes are important (themes 2.a to 2.e, Table 2).

Theme 2.a (Table 2) summarises the executives' opinion that ITS suppliers need to develop processes to sustain and maintain market position. Their firm's use of past events (like process breakdown and the resultant discontent) to initiate process innovation is perceived to be disappointing and a sign of systemic (reactive) failure:

"So there isn't a bigger indictment of process innovation than end-buyer dissatisfaction. End-buyer dissatisfaction is the failure point. [...] If you allow endbuyer dissatisfaction to be a driver for process innovation then you are allowing yourself to be reactive rather than be ahead of the curve." 


\subsubsection{Assessing the value of process change: relational, organisational and internal tensions}

A clear pattern across narratives related to the how the value of process change, as understood by a supplier representative inside a relationship is not matched with the value perceived by the buyers or the supplier's organisation. ITS supplier organisations (those not involved in the specific relationship) therefore struggle to capture the depth and complexity of buyer and overall employee dissatisfaction (as captured in Theme 2.b, Table 2). As a result, suppliers' actions in response to discontent feedback and the resultant outcome are somewhat blinded to the complexities of interaction.

"A new process was started for delivery excellence more than a year ago. Do we know why the delivery excellence process was changed? No! Do we know what this new process has achieved in the last year? No, we had no answers! [...] I am not sure if the organisation is really streamlining the process, there is [a] lack of communication with the customers [and] employees. The final perception is that dissatisfaction is not captured, resulting in speculations on the negative side."

A different form of process-based problem emphasised service suppliers changing organisational practices and/or processes but absenting buyers and specific actors in the relationship. No real organisation intent (or action) to address discontent was at play; rather the wider supplier business initiated process innovation with a view to maximising short-term financial outcomes (themes 2.c and 2.d, Table 2):

"Our company collects customer satisfaction [feedback] and the client buyers [of a large Insurance Customer] rated us a poor. The management initiated a lot of discussion, but this did not translate into anything of value for the customer or for the employees working on the account. Let me tell you there was no communication of process changes to the customer or the employees. On the floor we never saw any change. There is complete lack of organisational intent to listen to its employees or customers so the changes our company made are of no value." 
"We had a consulting opportunity [...] the customer accepted the pricing and deliverables and asked my organisation to create a statement of work; at this point a new process was followed and the Pricing team revised the quoted value and doubled it. The end-customer was not happy with the revised quote. The problem is that the new Pricing team is not part of the sales process, they do not understand the endcustomer needs, but they provide the final project value, which is not the same as the quoted value. This process does not work, we are all dissatisfied but nobody is listening."

\subsubsection{The identity of dissatisfaction feedback and process innovation}

Buyer feedback was one of the many sources of information that influence process innovation; therefore the source - the level of buyer dissatisfaction - loses its identity during the innovation process (Theme 2.e.i, Table 2). Further, the heterogeneity of buyer needs makes it difficult to draw an association between buyer dissatisfaction and firm-level outputs due to causal ambiguity (Theme 2.e.ii, Table 2). Finally, discontent did not dictate a solution because it is a firm that is in control of the ultimate output; this is because the firm has diverse options to respond to dissatisfaction (Theme 2.e.iii, Table 2). :

"I think it [process innovation] is taking feedback from the end-buyers and building it into your own differentiators. So you are taking inputs from external stakeholders and you are building [them] into a bigger thing, whether it is a product, an output, or a process. The end-buyer input is only one component of the finished output, although [it is] an important component. By the time all inputs get into the output, it is difficult to recognise it from outside; the end-buyer input is lost in the mix."

In response to the inability of an ITS supplier to extract value from buyer dissatisfaction an account provided by a respondent is revealing: his firm failed to respond to dissatisfaction, lost a substantial share of the business to its competitors, and made no attempt to integrate buyers and employees to co-create a solution: 
"My company changed their [employee] bench policy without engaging key stakeholders [...] the Resource Management System sends out an automated email to the employees that their project is ending and they need to find a new project, or extend the current project, or they have to relocate back to India. 10 people of the project team got this automated email and 8 of them left the company immediately and found another job. I think dissatisfaction is not captured, nobody is engaged. Nobody has the long-term view."

Complimenting this insight is that suppliers, when experiencing high dissatisfaction, seem not to be motivated to adopt a long-term view or to collaborate with the buyers to find a resolution because these firms believe they already understand the process problem:

"Say an organisation is focused on a service delivery that is not happening as expected, [under these circumstances] the objective is not to undertake radical change, so the organisation does not collaborate with end-buyers because it already knows the problem."

Summarising the qualitative evidence, it is too simplistic to link buyer dissatisfaction and process innovation (Figure 3). The buyers' needs and their abilities to contribute to process innovation are heterogeneous, and buyers have diverse relationships with their suppliers. Suppliers also consider an increase in satisfaction (reduction in dissatisfaction) is not worth acting on, as it is often difficult to quantify the cost and connect benefit to outcomes of such investments. Second, a buyer's (dis)satisfaction level is not necessarily a signal of the future potential of the relationship: Buyer dissatisfaction (arising from multiple reasons) appears to be treated as an on-going friction in a relationship with some detachment occurring between the wider business and specific stakeholders to a relationship. 


\section{DISCUSSION}

Suppliers do not adjust their collaboration with buyers because of buyer dissatisfaction, explaining the lack of association between process innovation, buyer collaboration and internal resource commitment in our results.

The motivation to begin process innovation is either initiated within the relationship, or imposed by external factors (both environmental factors and external stakeholders). In the case of external factors, it seems less likely to yield a positive process innovation, as the external stakeholders do not understand the relationship with depth, leading to a degree of resistance to change. Suppliers are expected to benefit from process innovation, resulting from failure resolution, because it generates efficiency gains through cost controls and improved capabilities. However, these benefits are subject to the creation of an organisational environment that is supportive of change and creates a unified focus on factors that will deliver value to the buyers. This seems to indicate a need for concordance about the status of the relationship within the wider buyer and supplier organisations. This view is usefully developed in terms of unit of focus by Dahlsten (2003, p. 73) who observes "Companies must move beyond merely fixing what has 'gone wrong' to developing what will 'go right' by refocusing on the actual customer experience".

Within the relational context a link might be expected between process innovation and consumer feedback. However, our study does not find such a link. Our finding is supported by research where customer satisfaction has no significant impact on the current or lagged (one- or two-period ahead) customer profitability, because of the financial cost associated with increasing satisfaction $(\mathrm{Yu}, 2007)$. Our research indicates that there is a time lag between dissatisfaction identification and problem resolution. There may also be a tendency to dissociate the connection between buyer discontent and the resulting changes. 
Improvements in processes also appear to have a benefit plateau, beyond which additional resources have a marginal impact and returns diminish, echoing similar findings from McCollough et al., (2000) and Maxham and Netemeyer, (2002). This is, again, because of a supplier's response to dissatisfaction is innately reactive. Initial attempts at rectification are motivated by exploiting a firm's existing capabilities for self-seeking short-term gain, but the ability for this movement to enable resource re-configuration is questionable (Lapré and Tsikriktsis, 2006). In the context of interaction it appears that dissatisfaction creates multiple short cycle episodes of reactive adjustment, which do not seem linked together.

This is not to say that the learning from past failures is not beneficial; suppliers use dissatisfaction feedback to understand why their processes have failed to meet buyer expectations or values. At the very least, dissatisfaction feedback helps a supplier to optimise processes and improve efficiencies. However, our study shows that extending the benefits past isolated event resolutions is challenging, primarily because of the complexity of transferring improvements and solutions between projects. Buyer dissatisfaction and process innovation causality seem therefore to focus more on perfecting existing capabilities within specific contexts.

In summary, our study suggests that buyer discontent is not a primary determinant of process innovation. . Although previous studies suggest that enhanced satisfaction leads to customer loyalty and positive business results, our findings do not bear this out. Several complications confound this association. Buyer satisfaction measures are poor indicators for the goodwill locked in buyer-supplier relationships. It could also reflect poor measures for repeat business or wholly positive deeper collaboration. Furthermore, the business value of satisfaction is difficult to assess (Slater and Narver, 1998; Keiningham et al., 2014). Despite the substantial literature on dissatisfaction our evidence points to need for more temporally sophisticated assessments of its role in process innovation. Our empirical evidence suggests 
firms are reactive and short-term focused, which leads to adaptive learning and incrementalism.

\section{CONCLUSIONS, IMPLICATIONS FOR PRACTICE AND FUTURE RESEARCH}

Our study explains three key issues that underscore the problematic nature of drawing a direct association between buyer dissatisfaction and process innovation. Firstly, high discontent is unlikely to translate into more innovation. This is because an existing process that is improved repetitively using dissatisfaction feedback suffers from diminishing returns (Lapré and Tsikriktsis, 2006; Keiningham et al. 2014). It is therefore doubtful if service providers use such discontent feedback as a proxy or replacement for general management strategy towards process innovation. Our results suggest that process innovations are specific to relationships and become difficult to transfer. Secondly, there is a time lag between dissatisfaction identification and problem resolution. However, relationships have innate levels of dissatisfaction that may be accounted for as existing by suppliers but not acted upon.

Thirdly, our study confirms that suppliers devote substantial resources in the collection of dissatisfaction feedback, however they often fail significantly to utilise all the information collected (Dahlsten, 2003). In our interviews, we learnt there is a gap between a supplier's interpretation of the value of the service to the buyer and the buyer's expectations. Managers regard discontent feedback as just one of the several inputs necessary to undertake transformation. This feedback may need to be collected as part of a wider (on-going) joint assessment process where the health of the relationship determines facets of short- and longterm interaction and resourcing. If dissatisfaction data is repeatedly not acted on, it poses questions about its redundancy, and could hinder purposive interaction in the long run. Managers may therefore need to take care when collecting information on satisfaction, as the supplier's response to dissatisfaction is impacted by other factors. Some buyer-supplier 
relations (outside of instrumental services) will benefit from not using buyer dissatisfaction questionnaires. Rather, it may be more suitable to re-orient certain relationships by proactively seeking solutions rather than reactively dealing with problems.

There are a series of future research directions, which the study prompts, with a key task to model the costs and benefits of reducing buyer dissatisfaction in other service provider-customer contexts. It will be interesting to assess if changing levels of buyer dissatisfaction triggers the future potential of the supplier-buyer relationship. One particular approach will be to use in-depth case studies of different forms of service exchange to evaluate how firms use buyer dissatisfaction feedback to enhance firm-level output. This will shed light on the methods used to record, analyse and translate buyer dissatisfaction feedback. Case studies could track the actions taken by firms in response to buyer dissatisfaction feedback, and allow studying if firms adapt their firm-level strategies in response to buyer dissatisfaction feedback. We would expect, as part of this interactive atmosphere, to account for the organisational conditions which impact the value extracted from buyer dissatisfaction feedback, as this is a significant determinant identified by our study. In particular, do firms that enhance firm-level outputs in response to buyer dissatisfaction feedback, exhibit specific management strategies? Employee-, buyer- and management-engagement may be key in this respect, both from a buyer and supplier perspective. Buyers may also have heterogeneous needs, so assessing how are they segmented, weighted, or translated into change objectives by suppliers will be insightful.

Finally it will be fruitful to explore how firms account for gaps between their interpretation of buyer dissatisfaction and the value perceived by its buyer. This requires studying the supplier's ability to translate buyer dissatisfaction feedback into short- and longterm improvement opportunities. It would then enlighten if buyer dissatisfaction feedback was key in determining incremental or radical innovation. This would be part of the 
development and empirical validation of the ITS firm's strategy to synthesise buyer dissatisfaction feedback. Within the context of an interactive lens we assume suppliers and buyers have several contact points. How buyer dissatisfaction feedback is holistically captured, synthesised, and shared would be revelatory.

\subsection{Limitations}

The results discussed in the paper should be viewed in light of the potential sources of bias discussed here. The operationalisation of key constructs and the focal industry of our study are likely to impact the implications drawn from the results. We also choose to focus on what Van der Valk et al. (2008) term 'instrumental services' so other patterns of service interaction will be useful to assess. In this study, we capture suppliers' perceptions of the levels of buyer dissatisfaction, thus future studies will benefit by comparing suppliers' perceptions with inputs from the buyers; although such studies will have to deal with additional problems. These issues are partly associated to the sheer number of buyers involved in services and are concerned with the fact these needs are heterogeneous but specific to relationships. Researchers will also face challenges due to the varying roles buyers play in the innovation process and the fact that buyer dissatisfaction might provide learning for multiple projects; despite these drawbacks an approach that incorporates buyer feedback will be very beneficial to this area of research. One potential methodological solution will be the adoption of multiple data sources within a case organisation. This will enable the synthesis of a supplier's perception of buyer dissatisfaction with that of inputs from its customers. The methods of study may include analysing buyer satisfaction survey results, assessing buyer actions, studying complaints, and examining repeat business patterns (Yi, 1990). 
Finally, suppliers will benefit from modifying their process innovation strategies in light of a continual evaluation of the level of buyer (dis)satisfaction as consumer expectations and their (dis)satisfaction change over the course of time (Nilsson-Witell and Fundin, 2005).

We find that ITS suppliers do not engage fully with their internal stakeholders, the employees, in devising a response to buyer discontent, an aspect that may be included in future studies.

\section{References}

ANDERSON, E. W. \& SULLIVAN, M. W. 1993. The Antecedents and Consequences of Customer Satisfaction for Firms. Marketing Science, 12(2), 125-143.

ANDERSON, K. \& MCADAM, R. 2004. A critique of benchmarking and performance measurement: Lead or lag? Benchmarking: An International Journal, 11(5), 465-483.

ASHOK, M., NARULA, R., \& MARTINEZ-NOYA, A., 2016. How do collaboration and investments in knowledge management affect process innovation in services?. Journal of Knowledge Management, 20(5), 1004-1024.

BARTLETT, J. E., KOTRLIK, J. W. \& HIGGINS, C. C. 2001. Organizational research: Determining appropriate sample size in survey research. Information technology, learning, and performance journal, 19(1), 43-50.

BARUCH, Y. \& HOLTOM, B. C. 2008. Survey response rate levels and trends in organizational research. Human Relations, 61(8), 1139-1160.

BILGRAM, V., BREM, A. \& VOIGT, K.-I. 2008. User-Centric Innovations in New Product Development - Systematic Identification of Lead Users Harnessing Interactive and Collaborative Online-Tools. International Journal of Innovation Management, 12(03), 419-458.

BRAUN, V. \& CLARKE, V. 2006. Using thematic analysis in psychology. Qualitative Research in Psychology, 3(2), 77-101.

BRAUN, V., CLARKE, V. \& TERRY, G. 2015. Thematic analysis. In: ROHLEDER, P. \& LYONS, A. (eds.) Qualitative Research in Clinical and Health Psychology.

CAMP, R. C. 1989. Benchmarking: the search for industry best practices that lead to superior performance. ASQC/Quality Resources.

CHIN, W. W. 1998a. Issues and Opinion on Structural Equation Modeling. MIS Quarterly, 22(1), vii-xvi.

CHIN, W. W. 1998b. The partial least squares approach for structural equation modeling (Chapter Ten). In: MARCOULIDES, G. A. (ed.) Modern methods for business research.

CHO, Y. C. \& SONG, J. 2012. The effects of customer dissatisfaction on switching behavior in the service sector. Journal of Business \& Economics Research, 10(10), 579-591.

CHURCHILL, G. A., JR. 1979. A Paradigm for Developing Better Measures of Marketing Constructs. Journal of Marketing Research, 16, 64-73.

COHEN, J. 1992. Quantitative methods in psychology: A power primer. Psychological Bulletin, 112(1), 155-159. 
COHEN, W. M. \& LEVINTHAL, D. A. 1990. Absorptive Capacity: A New Perspective on Learning and Innovation. Administrative Science Quarterly, 35, 128-152.

COOK, C., HEATH, F. \& THOMPSON, R. L. 2000. A Meta-Analysis of Response Rates in Web- or Internet-Based Surveys. Educational and Psychological Measurement, 60(6), 821-836.

CRESWELL, J. W. 2013. Research design: Qualitative, quantitative, and mixed methods approaches. Sage publications.

CRONBACH, L. 1951. Coefficient alpha and the internal structure of tests. Psychometrika, 16, 297-334.

DAHLSTEN, F. 2003. Avoiding the customer satisfaction rut. MIT Sloan Management Review, 44(4), 73-77.

DATTAKUMAR, R. \& JAGADEESH, R. 2003. A review of literature on benchmarking. Benchmarking: An International Journal, 10(3), 176-209.

D'ANTONE, S. \& SANTOS J. B. 2016. When purchasing professional services supports innovation. Industrial Marketing Management, 58,172-186.

DAVENPORT, T. H. 1993. Process Innovation: Reengineering Work Through Information Technology. HBS Press Books.

DONG, B., EVANS, K. R. \& ZOU, S. 2008. The effects of customer participation in cocreated service recovery. Journal of the Academy of Marketing Science, 36(1), 123137.

DOROSHENKO, M., MILES, I. \& VINOGRADOV, D. 2013. Knowledge Intensive Business Services as Generators of Innovations. Higher School of Economics Research Paper No. WP BRP, 12.

DUBOIS, A. \& GADDE, L.E., 2002. Systematic combining: an abductive approach to case research. Journal of business research, 55(7), 553-560.

FERGUSON, J. L. \& JOHNSTON, W. J. 2011. Customer response to dissatisfaction: A synthesis of literature and conceptual framework. Industrial Marketing Management, 40(1), 118-127.

FORD, D. \& MOUZAS, S. 2013. The theory and practice of business networking. Industrial Marketing Management, 42(3), 433-442.

FOSS, N. J., LAURSEN, K. \& PEDERSEN, T. 2011. Linking Customer Interaction and Innovation: The Mediating Role of New Organizational Practices. Organization Science, 22(4), 980-999.

FREEMAN, C. 2010. Formal scientific and technical institutions in the national system of innovation. In: LUNDVALL, B.-Å. (ed.) National systems of innovation: Toward a theory of innovation and interactive learning.

FRISHAMMAR, J., KURKKIO, M., ABRAHAMSSON, L. \& LICHTENTHALER, U. 2012. Antecedents and Consequences of Firms' Process Innovation Capability: A Literature Review and a Conceptual Framework. IEEE Transactions on Engineering Management, 59(4), 519-529.

FROW, P., MCCOLL-KENNEDY, J. R. \& PAYNE, A. 2016. Co-creation practices: Their role in shaping a health care ecosystem. Industrial Marketing Management, 56, 2439.

FUNDIN, A. \& ELG, M. 2010. Continuous learning using dissatisfaction feedback in new product development contexts. International Journal of Quality \& Reliability Management, 27(8), 860-877.

HAIR, J. F., BLACK, W. C., BABIN, B. J. \& ANDERSON, R. E. 2010. Multivariate Data Analysis, Prentice Hall.

HAIR, J. F., HULT, G. T. M., RINGLE, C. \& SARSTEDT, M. 2013. A Primer on Partial Least Squares Structural Equation Modeling (PLS-SEM). SAGE Publications. 
HAKANSSON, H. ed., 1982. International marketing and purchasing of industrial goods: An interaction approach. Wiley.

HAKANSSON, H. \& SNEHOTA, I., eds., 1995. Developing relationships in business networks. Routledge.

HAKANSSON, H. \& WALUSZEWSKI, A., 2002. Managing Technological Development. IKEA, the environment and technlogy. Routledge.

HAKANSSON, H., FORD, D., GADDE, L.E., SNEHOTA, I. \& WALUSZEWSKI, A., 2009. Business in networks. JohnWiley \& Sons.

HENSELER, J., RINGLE, C. \& SINKOVICS, R. R. 2009. The use of partial least squares path modeling in international marketing. New Challenges to International Marketing. Advances in international marketing, 20(1), 277-319.

HIENERTH, C., VON HIPPEL, E. \& JENSEN, M. B. 2014. User community vs. producer innovation development efficiency: A first empirical study. Research Policy, 43(1), 190-201.

JOHNSON, R. B., ONWUEGBUZIE, A. J. \& TURNER, L. A. 2007. Toward a Definition of Mixed Methods Research. Journal of Mixed Methods Research, 1(2), 112-133.

JOHNSON, W.H. \& MEDCOF, J.W., 2007. Motivating proactive subsidiary innovation: Agent-based theory and socialization models in global R\&D. Journal of International Management, 13(4), pp.472-487.

KANG, K. H. \& KANG, J. (2014), Do External Knowledge Sourcing Modes Matter for Service Innovation? Empirical Evidence from South Korean Service Firms, Journal of Product Innovation Management, 31(1), 176-191.

KARATEPE, O. M. 2006. Customer complaints and organizational responses: the effects of complainants' perceptions of justice on satisfaction and loyalty. International Journal of Hospitality Management, 25(1), 69-90.

KEININGHAM, T., GUPTA, S., AKSOY, L. \& BUOYE, A. 2014. The High Price of Customer Satisfaction. MIT Sloan Management Review, 55(3), 37-46.

KEUPP, M. M. \& GASSMANN, O. 2013. Resource constraints as triggers of radical innovation: Longitudinal evidence from the manufacturing sector. Research Policy, 42(8), 1457-1468.

KEUPP, M. M., PALMIÉ, M. \& GASSMANN, O. 2012. The Strategic Management of Innovation: A Systematic Review and Paths for Future Research. International Journal of Management Reviews, 14(4), 367-390.

KIM, H., PARK, N. \& LEE, J. 2014. How does the second-order learning process moderate the relationship between innovation inputs and outputs of large Korean firms? Asia Pacific Journal of Management, 31(1), 69-103.

KING, N. 2012. Doing template analysis. In: SYMON, G. \& CASSELL, C. (eds.) Qualitative organizational research: Core methods and current challenges.

KOGUT, B. \& ZANDER, U. 1992. Knowledge of the Firm, Combinative Capabilities, and the Replication of Technology. Organization Science, 3(3), 383-397.

KUMAR, V., AKSOY, L., DONKERS, B., VENKATESAN, R., WIESEL, T. \& TILLMANNS, S. 2010. Undervalued or Overvalued Customers: Capturing Total Customer Engagement Value. Journal of Service Research, 13(3), 297-310.

LAPRÉ, M. A. 2011. Reducing customer dissatisfaction: How important is learning to reduce service failure? Production and Operations Management, 20(4), 491-507.

LAPRÉ, M. A. \& TSIKRIKTSIS, N. 2006. Organizational Learning Curves for Customer Dissatisfaction: Heterogeneity across Airlines. Management Science, 52(3), 352-366.

LA ROCCA, A., MOSCATELLI, P., PERNA, A. \& SNEHOTA, I., 2016. Customer involvement in new product development in B2B: The role of sales. Industrial Marketing Management, 58, pp.45-57. 
LIETZ, P. 2010. Research into questionnaire design. International Journal of Market Research, 52(2), 249-272.

LI-HUA, Y. 2012. Customer satisfaction antecedents within service recovery context: Evidences from "Big 4" banks in China. Nankai Business Review International, 3(3), 284-301.

LÜTHJE, C. \& HERSTATT, C. 2004. The Lead User method: an outline of empirical findings and issues for future research. $R \& D$ Management, 34(5), 553-568.

MALERBA, F., NELSON, R., ORSENIGO, L. \& WINTER, S. 2007. Demand, innovation, and the dynamics of market structure: The role of experimental users and diverse preferences. Journal of Evolutionary Economics, 17(4), 371-399.

MAXHAM III, J. G. \& NETEMEYER, R. G. 2002. A Longitudinal Study of Complaining Customers' Evaluations of Multiple Service Failures and Recovery Efforts. Journal of Marketing, 66(4), 57-71.

MCCOLLOUGH, M. A., BERRY, L. L. \& YADAV, M. S. 2000. An Empirical Investigation of Customer Satisfaction after Service Failure and Recovery. Journal of Service Research, 3(2), 121-137.

MILES, I. 2006. Innovation in services. In: FAGERBERG, J., MOWERY, D. C. \& NELSON, R. (eds.) The Oxford handbook of innovation (Online).

MORSE, J. M. \& NIEHAUS, L. 2009. Mixed method design: Principles and procedures. Left Coast Pr.

NICOLAJSEN, H. W. \& SCUPOLA, A. 2011. KIBS and their users as co-creators of breakthrough innovation. In: SUNDBO, J. \& TOIVONE, M. (eds.) User-based Innovation in Services. Edward Elgar Publishing Limited.

NILSSON-WITELL, L. \& FUNDIN, A. 2005. Dynamics of service attributes: a test of Kano's theory of attractive quality. International Journal of Service Industry Management, 16(2), 152-168.

OECD 2005. Oslo manual: Guidelines for collecting and interpreting innovation data, Organisation for Economic Co-operation Development (OECD) publishing.

PODSAKOFF, P. M. \& ORGAN, D. W. 1986. Self-Reports in Organizational Research: Problems and Prospects. Journal of Management, 12(4), 531-544.

PRAHALAD, C. K. \& RAMASWAMY, V. 2004. Co-creation experiences: The next practice in value creation. Journal of Interactive Marketing, 18(3), 5-14.

RIDDER, F. 2013. Generation Y Will Reinvent Outsourcing. Gartner, ID:G00250544, 1-9.

RINGLE, C. M., WENDE, S. \& WILL, A. 2005. SmartPLS 2.0. www.smartpls.de.

SALTER, A. \& TETHER, B. S. 2014. Innovation in Services: An Overview. In: HAYNES, K. \& GRUGULIS, I. (eds.) Managing Services: Challenges and Innovation. Oxford University Press.

SANTOS, J.B. \& SPRING, M. 2015. Are knowledge intensive business services really coproduced? Overcoming lack of customer participation in KIBS. Industrial marketing management, 50, 85-96.

SAUERMANN, H. \& ROACH, M. 2013. Increasing web survey response rates in innovation research: An experimental study of static and dynamic contact design features. Research Policy, 42(1), 273-286.

SCHUHMACHER, M. C., \& KUESTER, S. (2012). Identification of lead user characteristics driving the quality of service innovation ideas. Creativity and Innovation Management, 21(4), 427-442.

SLATER, S. F. \& NARVER, J. C. 1998. Customer-Led and Market-Oriented: Let's Not Confuse the Two. Strategic Management Journal, 19(10), 1001-1006. 
SOSIK, J. J., KAHAI, S. S. \& PIOVOSO, M. J. 2009. Silver Bullet or Voodoo Statistics?: A Primer for Using the Partial Least Squares Data Analytic Technique in Group and Organization Research. Group \& Organization Management, 34(1), 5-36.

SUMO, R., VAN DER VALK, W., DUYSTERS, G. \& VAN WEELE, A., 2016. Using performance-based contracts to foster innovation in outsourced service delivery. Industrial Marketing Management, 59, pp.12-24.

SZYMANSKI, D. M. \& HENARD, D. H. 2001. Customer satisfaction: a meta-analysis of the empirical evidence. Journal of the Academy of Marketing Science, 29(1), 16-35.

TIKKANEN, H., ALAJOUTSIJÄRVI, K. \& TÄHTINEN, J. 2000. The Concept Of Satisfaction in Industrial Markets: A Contextual Perspective and a Case Study from the Software Industry. Industrial Marketing Management, 29(4), 373-386.

UKIS 2012. First Findings from the UK Innovation Survey 2011: Science and Innovation Analysis. UK BIS - Department for Business Innovation and Skills. http://www.bis.gov.uk/assets/biscore/science/docs/f/12-p107-first-findings-ukinnovation-survey-2011

VAN DER VALK, W. \& WYNSTRA, F. 2014. Variety in business-to-business services and buyer-supplier interaction: The case of cleaning services. International Journal of Operations \& Production Management, 34(2), 195-220.

VAN DER VALK, W., WYNSTRA, F. \& AXELSSON, B. 2008. An empirical investigation of interaction processes between buyers and sellers of business services. IMP Journal, 2(2), 3-24.

VON HIPPEL, E. 2005. Democratizing Innovation, The MIT Press.

WALTER, A. \& RITTER, T., 2003. The influence of adaptations, trust, and commitment on value-creating functions of customer relationships. Journal of Business \& Industrial Marketing, 18(4/5), 353-365.

WIESSMEIER, G.F., THOMA, A. \& SENN, C., 2012. Leveraging synergies between R\&D and key account management to drive value creation. Research-Technology Management, 55(3), 15-22.

WYNSTRA, F., AXELSSON, B., VAN DER VALK, W. 2006. An application - based classification to understand buyer - supplier interaction in business services. International Journal of Service Industry Management, 17(5), 474-496.

YI, Y. 1990. A critical review of consumer satisfaction. Review of marketing, 4(1), 68-123. YU, S.-H. 2007. An Empirical Investigation on the Economic Consequences of Customer Satisfaction. Total Quality Management \& Business Excellence, 18(5), 555-569. 


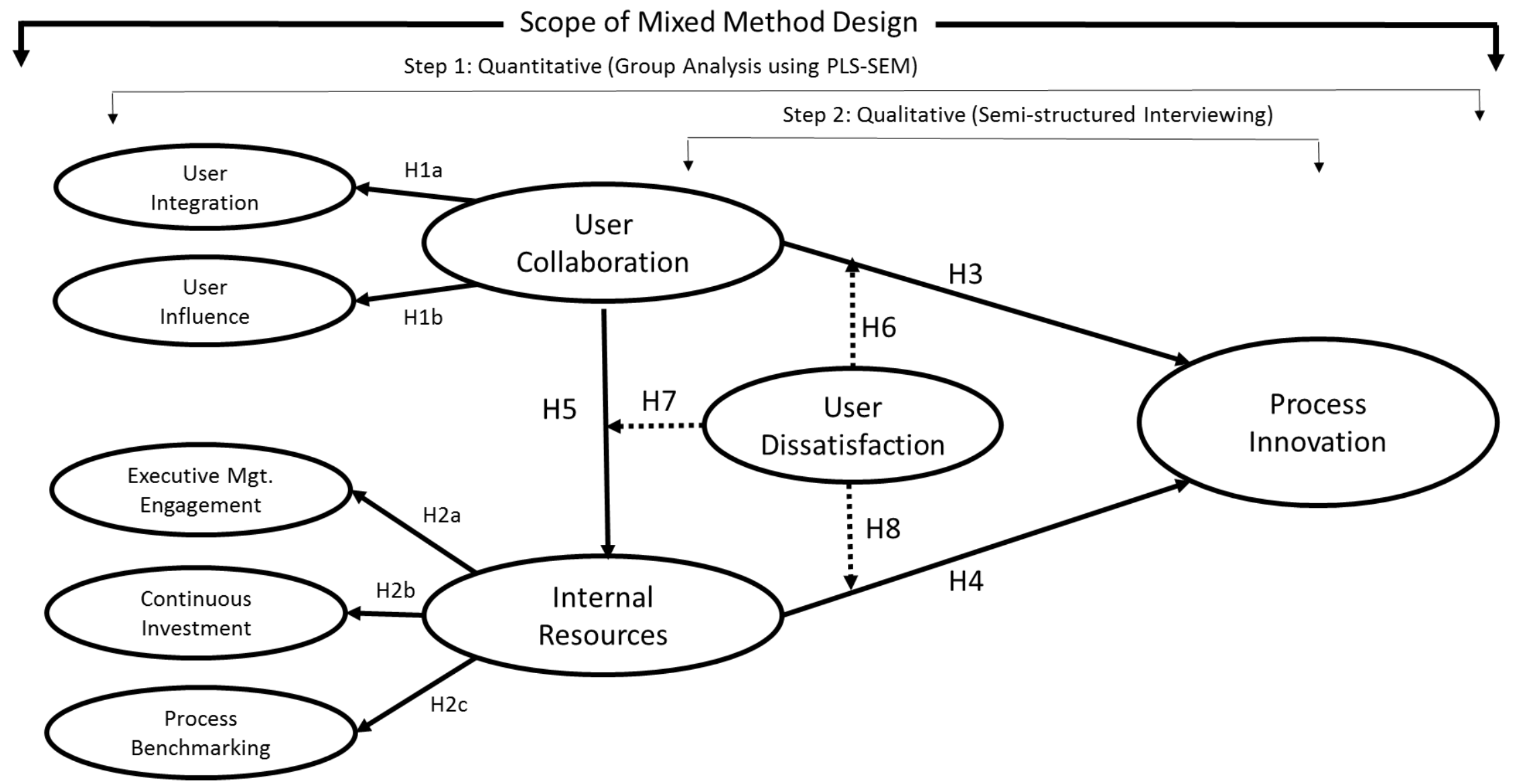

Moderator: User dissatisfaction: High versus low level of user dissatisfaction sub-groups

Mediator: Internal resources: User collaboration is hypothesised to have a direct effect on process innovation and an indirect effect through internal resources.

Figure 1: Research model and scope of mixed methods design 
Step 1: Quantitative Model Results (Group Analysis using PLS-SEM; User dissatisfaction is Moderator; Internal resources is Mediator)

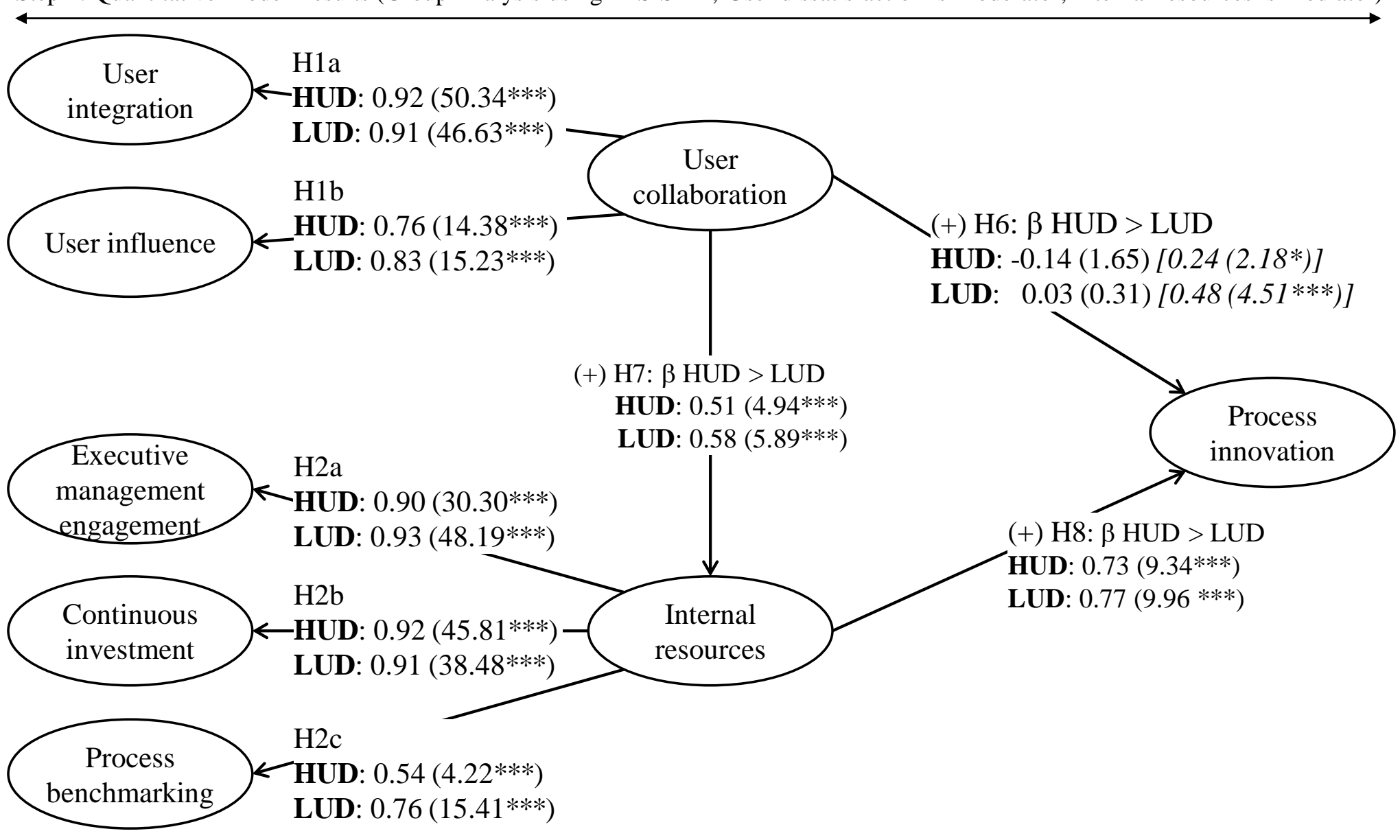

Notes:

Moderator: HUD - high-level of user dissatisfaction sub-group; LUD - low-level of user dissatisfaction sub-group

Numbers represent standardised path coefficients (t-statistic); * significant at 0.05 , *** significant at 0.001 (all two-tailed)

Numbers in italics and in [ ] are standardised path coefficients (t-statistic) for direct effect

Both the direct effect in the absence of the mediator, and the indirect effect through the mediator are studied

Figure 2: Path assessment - standardised path coefficient (t-statistic) for sub-groups 


\section{Step 2: Qualitative Interviewing Results}

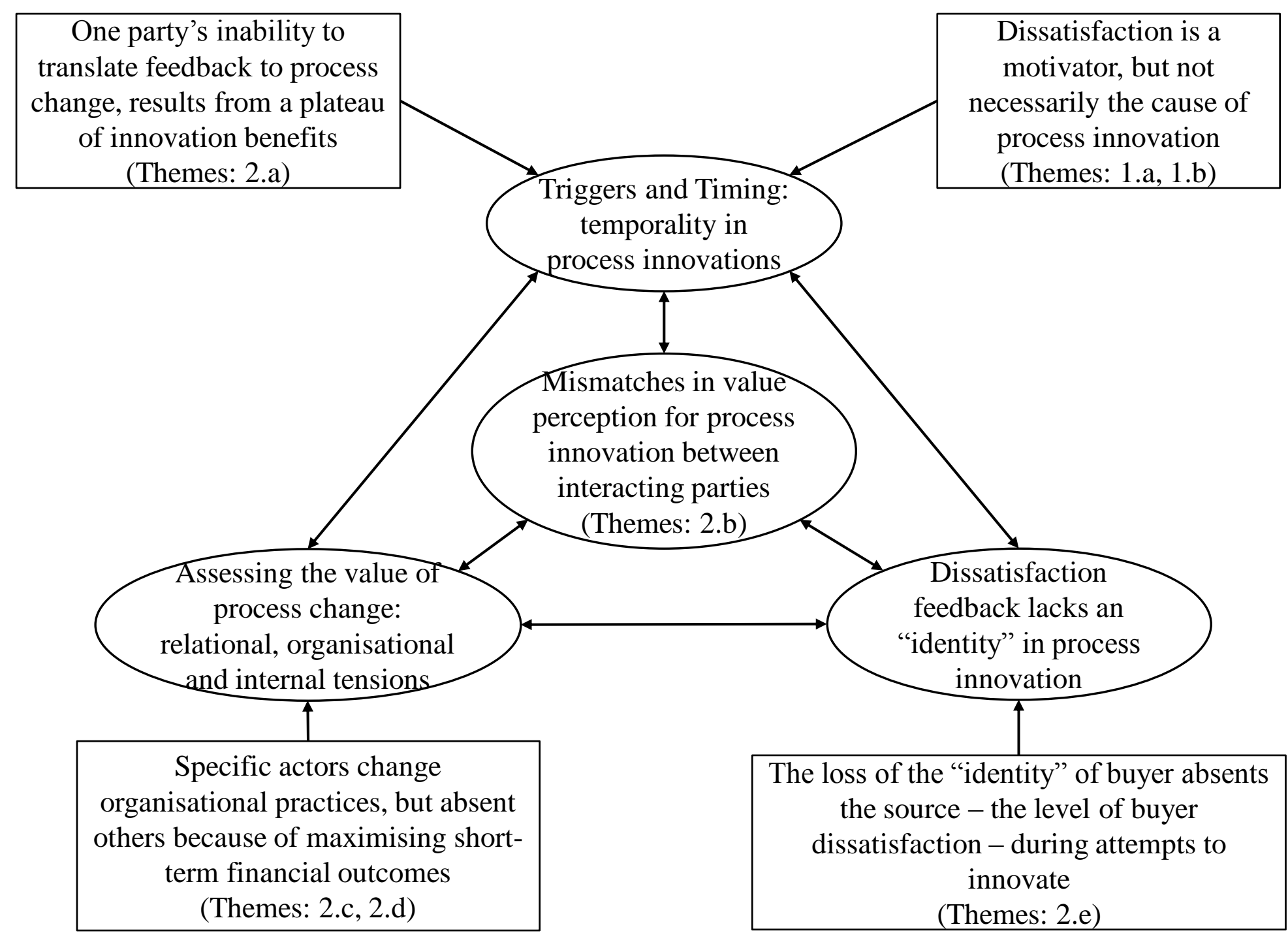

Figure 3: Explaining disconnections between buyer collaboration, internal resources and process innovation 
Table 1: Titles and professional experience of the interviewees

Title
Principal Consultant
Director
President
Business Transformation
Manager
CEO
Global Account Executive
Sr. Vice President \& Global
Head - Business Excellence,
Six Sigma \& Organization
Development
Industry Transformation
Consultant

Consultant

Corporate Process

Improvement Centre of

Excellence, Consultant

Consultant Director

Associate Practice Leader

Global Account Executive

Corporate Process

Excellence Consultant; Data Analysis and Metrics Expert

\section{Professional Experience at the time of discussions}

Over 31 years, roles include: subject matter expert (QMS, ISO, $\mathrm{CMMi}$ ), consultant (business planning, resource planning and management), Six Sigma Master Black Belt

Over 21 years, roles include: director, global head - small and medium business solutions, global head - Six Sigma consulting

Over 24 years, roles include: chief process officer, executive vice president, global business innovation lead, COO, VP continental Europe, CEO of not-for-profit organisation, assistant professor, researcher (holds a doctorate)

Over 19 years, roles include: business transformation manager, business manager, commercial lead and commercial contracts manager

Over 14 years, roles include: CEO, facilitator, keynote speaker, trustee of an NGO, software tester, CMM consultant, process improvement consultant, soft skills trainer, accountant

Over 20 years, roles include: director level positions within business development, growth and transformation

Over 20 years, roles include: business strategy and balanced scorecard deployment consultant, lean Six Sigma deployment lead, operations manager, lead Master Black Belt

Over 20 years, roles include: innovation services lead, business strategy and transformational change consultant, vice president, member of journal editorial board, value management researcher, senior lecturer, $\mathrm{PhD}$ supervisor, $\mathrm{PhD}$ examiner (holds a doctorate)

Over 17 years, roles include: subject matter expert - Six Sigma (Master Black Belt), process improvement consultant, lead trainer, QA assessor

Over 23 years, roles include: director of development, consultant director, QA manager, project manager, research officer

Over 14 years, roles include: associate director - business process management solutions \& presales, process improvement consultant, Six Sigma Black Belt, founder and SBU head

Over 21 years, roles include: global account executive, strategic global pursuit lead, enterprise client delivery executive, IT portfolio executive, delivery executive

Over 13 years, roles include: Six Sigma Master Black Belt, consultant (functional, process improvement), lead trainer for statistics and quantitative methodology, data visualization and analytics consultant 
Table 2: Final hierarchical coding template exploring the relationship between buyer dissatisfaction and process innovation

\begin{tabular}{|c|c|}
\hline Level & Themes \\
\hline 1 & $\begin{array}{l}\text { Expect a relationship (but there is a time lag between the expression of dissatisfaction } \\
\text { and the implementation of process change) }\end{array}$ \\
\hline 1.a & Buyer dissatisfaction precedes process innovation \\
\hline 1.b & Unmet buyer needs and existing problems motivate process change \\
\hline 2 & Do not expect a relationship \\
\hline 2.a & $\begin{array}{l}\text { Process innovation is necessary to stay competitive (hence short-sighted to } \\
\text { undertake process change as a result of dissatisfaction) }\end{array}$ \\
\hline 2.b & Process change value as perceived by the firm does not match value to the buyers \\
\hline 2.c & Lack of organisational intent (and action) to address buyer discontent \\
\hline 2.d & Insufficient investment to learn from buyer experiences \\
\hline 2.e & Not feasible to draw a relationship due to the heterogeneity issue \\
\hline 2.e.i & Process innovation outcomes impacted by many factors \\
\hline 2.e.ii & Heterogeneous reasons for buyer dissatisfaction \\
\hline 2.e.iii & Heterogeneous firm-level responses to buyer discontent \\
\hline
\end{tabular}

Table 3: The outer model's reliability and validity for the sub-groups

\begin{tabular}{|c|c|c|c|c|}
\hline \multirow[t]{2}{*}{ Constructs } & \multicolumn{4}{|c|}{\begin{tabular}{|c|} 
Sub-groups \\
High buyer dissatisfaction|Low buyer dissatisfaction
\end{tabular}} \\
\hline & AVE & $\begin{array}{l}\text { Composite } \\
\text { reliability }\end{array}$ & AVE & $\begin{array}{l}\text { Composite } \\
\text { reliability }\end{array}$ \\
\hline Process innovation & 0.66 & 0.92 & 0.76 & 0.95 \\
\hline Buyer collaboration & 0.55 & 0.92 & 0.62 & 0.94 \\
\hline Buyer integration & 0.74 & 0.94 & 0.76 & 0.95 \\
\hline Buyer influence & 0.78 & 0.93 & 0.86 & 0.96 \\
\hline Internal resource commitment & 0.52 & 0.91 & 0.65 & 0.95 \\
\hline Continuous investment & 0.68 & 0.89 & 0.78 & 0.93 \\
\hline Executive management engagement & 0.73 & 0.91 & 0.82 & 0.95 \\
\hline Process benchmarking & 0.89 & 0.94 & 0.90 & 0.95 \\
\hline n (sample size) & & .00 & & 00 \\
\hline Model $R^{2}$ & & 45 & & 62 \\
\hline
\end{tabular}


Table 4: Discriminant validity, the correlations of constructs and $\sqrt{ }$ AVE test

\begin{tabular}{|c|c|c|c|c|c|c|}
\hline \multirow[t]{2}{*}{ Constructs } & \multicolumn{6}{|c|}{ Sub-groups (correlations) } \\
\hline & High & $r$ diss & action & Low & dissat & tion \\
\hline A. Buyer collaboration & 0.74 & & & 0.79 & & \\
\hline B. Internal resources & 0.51 & 0.72 & & 0.58 & 0.81 & \\
\hline C. Process innovation & 0.24 & 0.66 & 0.81 & 0.48 & 0.79 & 0.87 \\
\hline
\end{tabular}

Note: The bold and italicised numbers along the diagonal are square root of AV 
Table 5: Inner model assessment and goodness-of-fit indices for the sub-groups

\begin{tabular}{|c|c|c|c|c|c|c|c|c|c|c|c|c|}
\hline \multirow[b]{2}{*}{$\begin{array}{l}\text { Endogenous } \\
\text { constructs }\end{array}$} & \multicolumn{6}{|c|}{ High buyer dissatisfaction } & \multicolumn{6}{|c|}{ Low buyer dissatisfaction } \\
\hline & $\begin{array}{c}\text { VIF } \\
\text { Values }\end{array}$ & $\mathbf{R}^{2}$ & $\underset{\mathbf{a}}{\operatorname{Adj} .} \mathbf{R}^{2}$ & $\Delta \mathbf{R}^{2}$ & $\begin{array}{l}\mathbf{f}^{2} \\
b\end{array}$ & $\begin{array}{c}\mathbf{Q}^{2} \\
\mathrm{c}\end{array}$ & $\begin{array}{c}\text { VIF } \\
\text { Values }\end{array}$ & $\mathbf{R}^{2}$ & $\underset{\mathbf{a}}{\operatorname{Adj} .} \mathbf{R}^{2}$ & $\Delta \mathbf{R}^{2}$ & $\begin{array}{l}\mathbf{f}^{2} \\
\mathrm{~b}\end{array}$ & $\begin{array}{c}\mathbf{Q}^{2} \\
\mathbf{c}\end{array}$ \\
\hline Process innovation & & 0.45 & 0.44 & & & 0.25 & & 0.62 & 0.61 & & & 0.44 \\
\hline Buyer collaboration & 1.35 & & & 0.44 & 0.03 & & 1.51 & & & 0.62 & 0.00 & \\
\hline Internal resources & 1.35 & & & 0.07 & 0.70 & & 1.51 & & & 0.24 & 1.03 & \\
\hline Internal resources & & 0.26 & 0.25 & & & 0.13 & & 0.34 & 0.33 & & & 0.22 \\
\hline
\end{tabular}

${ }^{a}$ Adjusted $R^{2}=1-\left(1-R^{2}\right) *(n-1) /(n-v-1)$, where $n=$ sample size and $v=$ number of predictor variables for the endogenous construct

${ }^{\mathrm{b}} \mathrm{f}^{2}=\left(\mathrm{R}^{2}\right.$ included $-\mathrm{R}^{2}$ excluded $) /\left(1-\mathrm{R}^{2}\right.$ included $)$

${ }^{\mathrm{c}}$ cross-validated redundancy approach 
Table 6: Construct mean comparison across the sub-groups

\begin{tabular}{|c|c|c|c|c|c|c|c|}
\hline \multirow[t]{3}{*}{ Constructs } & \multicolumn{4}{|c|}{ Sub-groups } & \multirow{3}{*}{$\begin{array}{c}\text { Mean } \\
\text { difference }\end{array}$} & \multirow{3}{*}{$\begin{array}{c}\text { t-test for } \\
\text { Equality of } \\
\text { Means } \\
\text { t-statistic }\end{array}$} & \multirow{3}{*}{$\begin{array}{c}\text { Sig.(two } \\
\text {-tailed) }\end{array}$} \\
\hline & \multicolumn{2}{|c|}{$\begin{array}{l}\text { High buyer } \\
\text { dissatisfaction }\end{array}$} & \multicolumn{2}{|c|}{$\begin{array}{c}\text { Low buyer } \\
\text { dissatisfaction }\end{array}$} & & & \\
\hline & Mean & Std Dev. & Mean & Std Dev. & & & \\
\hline Buyer collaboration & 3.25 & 1.10 & 3.67 & 1.23 & -0.42 & -2.09 & 0.04 \\
\hline Buyer integration & 3.48 & 1.40 & 3.81 & 1.44 & -0.33 & -1.38 & ns \\
\hline Buyer influence & 2.93 & 1.11 & 3.48 & 1.34 & -0.55 & -2.61 & 0.01 \\
\hline Internal resources & 3.43 & 1.19 & 3.49 & 1.35 & -0.06 & -0.30 & $n s$ \\
\hline Continuous investment & 3.66 & 1.38 & 3.69 & 1.51 & -0.03 & -0.11 & ns \\
\hline Executive management engagement & 3.18 & 1.33 & 3.40 & 1.52 & -0.22 & -0.88 & ns \\
\hline Process benchmarking & 3.50 & 1.76 & 3.30 & 1.52 & 0.20 & 0.70 & ns \\
\hline Process innovation & 2.95 & 1.37 & 3.10 & 1.51 & -0.16 & -0.64 & $n s$ \\
\hline
\end{tabular}

The Levene's test for equality of variances reported significance values of greater than 0.05 for all constructs, thus the t-test values are reported for 'equal variances assumed' Mean values are in reference to a one (strongly agree) to seven (strongly disagree) scale, thus lower values indicate higher joint process innovation, buyer collaboration (and its first-order constructs) and internal resource commitments (and its first-order constructs) results. 
Table 7: Differences in standardised path coefficients across the sub-groups

\section{Pathways}

H3 (+) Buyer collaboration -> Process innovation (direct effect in the absence of mediator)

H6 (+) Buyer collaboration -> Process innovation (indirect effect in the presence of mediator)

H4 and H8 (+) Internal resources -> Process innovation

H5 and H7 (+) Buyer collaboration -> Internal resources

a Standardised path coefficients' differences are calculated between High buyer dissatisfaction and Low buyer dissatisfaction sub-groups.

${ }^{\mathrm{b}}$ One-tailed test for significance, ns means the t-statistic of the difference is not significant.

\section{t-statistic of path coefficient differences ${ }^{\text {a }}$}

Sig. ${ }^{b}$

$-1.61$

ns

ns

ns

$-0.49$

ns

Table 8: Hypotheses test results and implications for qualitative study

\begin{tabular}{|l|l|l|}
\hline $\begin{array}{l}\text { Hypothesis } \\
\text { number }\end{array}$ & $\begin{array}{l}\text { Evidence for support } \\
\text { H1 }\end{array}$ & $\begin{array}{l}\text { Implications for } \\
\text { qualitative study }\end{array}$ \\
\hline H2 & $\begin{array}{l}\text { Yes; internal resource commitment is a second-order } \\
\text { construct }\end{array}$ & $\begin{array}{l}\text { Howe } \\
\text { commitment manifest? }\end{array}$ \\
\hline H3 & $\begin{array}{l}\text { Yes; there is positive direct impact of buyer collaboration on } \\
\text { process innovation, in absence of mediator }\end{array}$ & None \\
\hline H4 & $\begin{array}{l}\text { Yes; there is positive direct impact of internal resources on } \\
\text { process innovation }\end{array}$ & None \\
\hline H5 & $\begin{array}{l}\text { Yes; impact of buyer collaboration on process innovation is } \\
\text { fully mediated by internal resources }\end{array}$ & None \\
\hline H6 & $\begin{array}{l}\text { No; direct impact of buyer collaboration on process } \\
\text { innovation is NOT moderated by level of buyer } \\
\text { dissatisfaction }\end{array}$ & $\begin{array}{l}\text { How does the context of } \\
\text { interact influence this } \\
\text { relationship? }\end{array}$ \\
\hline H7 & $\begin{array}{l}\text { No; indirect impact of buyer collaboration on process } \\
\text { innovation (through internal resources) is NOT moderated by by } \\
\text { level of buyer dissatisfaction }\end{array}$ & $\begin{array}{l}\text { How important is internal } \\
\text { resource commitment as the } \\
\text { enabler for innovation? }\end{array}$ \\
\hline H8 & $\begin{array}{l}\text { No; direct impact of internal resources on process innovation } \\
\text { is NOT moderated by level of buyer dissatisfaction }\end{array}$ & $\begin{array}{l}\text { Is dissatisfaction therefore } \\
\text { ancillary to resourcing } \\
\text { decisions? }\end{array}$ \\
\hline
\end{tabular}




\section{Appendix 1}

The measurement scale and model loadings for the sub-groups

\begin{tabular}{|c|c|c|c|}
\hline \multirow[t]{2}{*}{ Construct-Indicators } & \multirow[t]{2}{*}{ Scale Development } & \multicolumn{2}{|c|}{ Sub-groups } \\
\hline & & $\begin{array}{c}\text { High buyer dissatisfaction } \\
1^{\text {st }} \text { order outer } \\
\text { loading }\end{array}$ & $\begin{array}{c}\text { Low buyer dissatisfaction } \\
1^{\text {st }} \text { order outer } \\
\begin{array}{c}2^{\text {nd }} \text { order outer } \\
\text { loading }\end{array} \\
\text { loading }\end{array}$ \\
\hline Process Innovation $(\mathrm{PI})$ & \multirow{4}{*}{$\begin{array}{l}\text { Created five reflective } \\
\text { indicators to capture the } \\
\text { depth and breadth of process } \\
\text { innovation outcomes (OECD, } \\
\text { 2005; UKIS, 2012). }\end{array}$} & & \\
\hline $\begin{array}{l}\text { Our organisation has implemented a new or significantly } \\
\text { improved process in the last year: }\end{array}$ & & & \\
\hline PI1 across the business unit & & 0.81 & 0.83 \\
\hline PI2 across group companies & & 0.78 & 0.83 \\
\hline \multicolumn{4}{|l|}{$\begin{array}{l}\text { Our organisation implemented 'process innovation' that in } \\
\text { the last year: }\end{array}$} \\
\hline PI3 increased profit margin on sales & & 0.84 & 0.92 \\
\hline PI4 led to growth in sales/turnover & & 0.77 & 0.92 \\
\hline PI5 impacted multiple systems & & 0.81 & 0.83 \\
\hline PI6 provided competitive advantage & & 0.87 & 0.90 \\
\hline Buyer dissatisfaction (UD) & \multirow{7}{*}{$\begin{array}{l}\text { Created four reflective } \\
\text { indicator based on the } \\
\text { definition adopted }(Y i, 1990)\end{array}$} & \multirow[t]{7}{*}{ Used as a moderator } & \multirow[t]{7}{*}{ Used as a moderator } \\
\hline $\begin{array}{l}\text { The end buyers that collaborated in 'process innovation' } \\
\text { with our organisation: }\end{array}$ & & & \\
\hline UD1 had demands that were unsatisfied & & & \\
\hline $\begin{array}{l}\text { UD2 were dissatisfied with existing delivery } \\
\text { methods }\end{array}$ & & & \\
\hline UD3 were dissatisfied with existing product & & & \\
\hline methods & & & \\
\hline $\begin{array}{l}\text { UD4 were dissatisfied with existing service } \\
\text { methods }\end{array}$ & & & \\
\hline
\end{tabular}




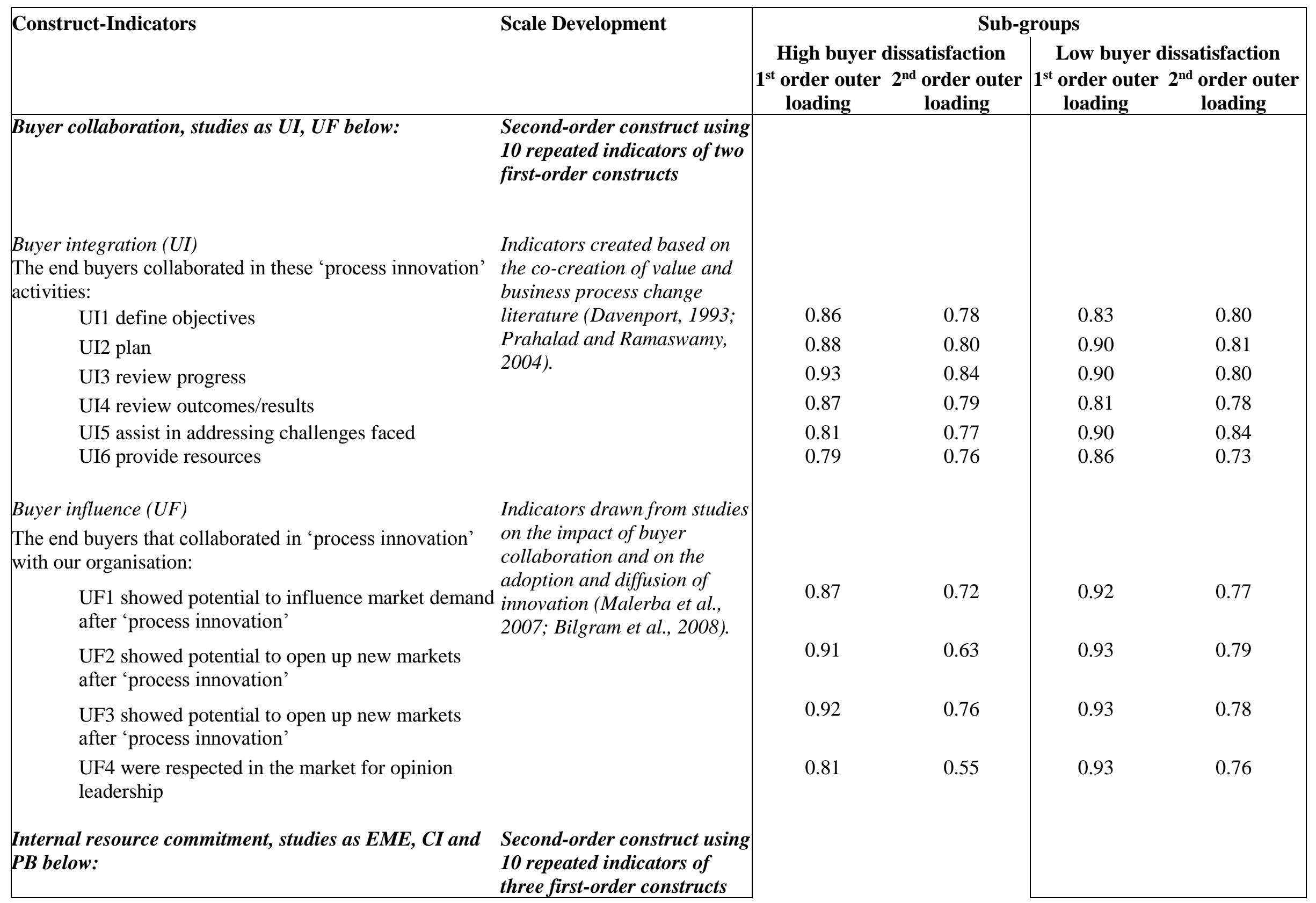




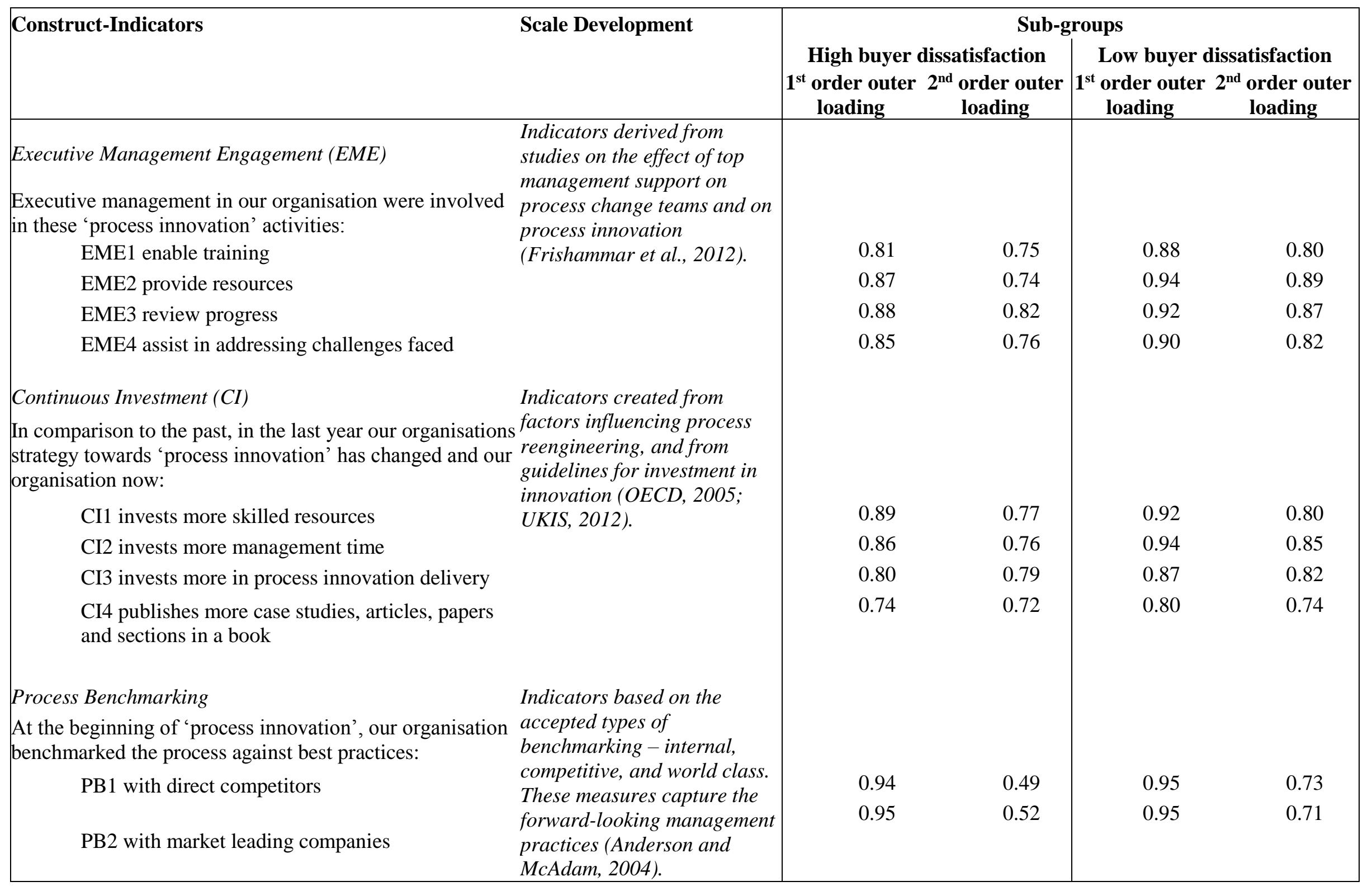

